\title{
Genetic Association between the XPG Asp1104His Polymorphism and Head and Neck Cancer Susceptibility: Evidence Based on a Meta-Analysis
}

\author{
Hua-Yong Jiang ${ }^{1 *}$, Yong Zeng ${ }^{2 \&}$, Wei-Dong $\mathrm{Xu}^{1}$, Chuan $\mathrm{Liu}^{3}$, Ya-Jie Wang ${ }^{3 *}$, \\ Ya-Di Wang ${ }^{1 *}$
}

\begin{abstract}
Background: Previous studies evaluating the association between the xeroderma pigmentosum group G (XPG) Asp1104His polymorphism and head and neck cancer susceptibility have proven controversial. This meta-analysis of the literature was performed to obtain a more precise estimation of the relationship. Materials and Methods: We systematically searched PubMed, Embase and Web of Science with a time limit of Dec 18, 2014. Odds ratios (ORs) with $95 \%$ confidence intervals (CIs) were used to assess the strength of any association. Results: We performed a meta-analysis of eight published case-control studies, including 3,621 cases and 5,475 controls. Overall, no significant association was found between the XPG Asp1104His polymorphism and head and neck cancer susceptibility under all genetic models. In the subgroup analysis by ethnicity, the XPG Asp1104His polymorphism had statistically significant association with elevated head and neck cancer risk under CC vs GG $(\mathrm{OR}=1.24,95 \% \mathrm{CI}=1.00 \sim 1.54)$ and the recessive model $(\mathrm{OR}=1.22,95 \% \mathrm{CI}=1.01 \sim 1.46)$ in Asian populations. A similar result was found under $\mathrm{CC}$ vs $\mathrm{GG}(\mathrm{OR}=1.22,95 \% \mathrm{CI}=1.01 \sim 1.47)$ in the population based subgroup by source of control. When performed by tumor site, the XPG Asp1104His polymorphism had statistically significant association with elevated laryngeal cancer under all genetic models (CC vs GG: $O R=1.59,95 \%$ CI=1.16 2.19; GC vs GG: $O R=1.38,95 \% \mathrm{CI}=1.10 \sim 1.72$; dominant model: $\mathrm{OR}=1.42,95 \% \mathrm{CI}=1.15 \sim 1.74$; recessive model: $\mathrm{OR}=1.36$, 95\% CI=1.02 1.81). Conclusions: This meta-analysis suggested that the XPG Asp1104His polymorphism is a risk factor for head and neck cancer susceptibility, especially for laryngeal cancer and in Asian populations.
\end{abstract}

Keywords: XPG Asp1104His - polymorphism - head and neck cancer - meta-analysis

Asian Pac J Cancer Prev, 16 (9), 3645-3651

\section{Introduction}

Head and neck cancer (HNC), which includes cancers of the oral cavity, pharynx, hypopharynx, and larynx, is one of the most common cancers worldwide (Siegel et al., 2014). It accounts for nearly $3 \%$ of all incident malignancies in the United States with an estimated 52, 610 new cases and 11, 500 deaths from HNC in 2012 (Siegel et al., 2012). To date, there are ample evidences indicating that $\mathrm{HNC}$ is a complex multifactorial disorder involving genetic factors, lifestyle, tobacco smoke, alcohol consuming, and environmental factors (Shammaa et al., 2008; Liu et al., 2012; Mokhtari., 2012; Smith et al., 2012) and some low penetrant genes have been identified as potential HNC susceptibility genes (Hopkins et al., 2008; Arora et al., 2012).

Among them, an important one is the xeroderma pigmentosum group $\mathrm{G}(X P G)$ gene, also known as the excision repair cross complementing group 5 (ERCC5) gene, the $X P G$ gene is located on chromosome 13q22-q33, encodes a 1186 amino-acid protein that functions as an endonuclease, cutting the DNA at the 3' terminus during the DNA repair process via the amino acids located in the $\mathrm{N}$-terminus of the protein (Emmert et al., 2001; Clarkson, 2003). It is a member of the flap structure-specific endonuclease 1 (FEN1) family and encodes a protein of 1186 amino acids. The primary structure of human XPG protein harbors the $\mathrm{N}$ - and Inuclease domains that are highly conserved, which together form the nuclease core (Melis et al., 2013). Single nucleotide polymorphisms (SNPs) in $X P G$ gene have been discovered in human populations, the Asp1104His polymorphism (rs17655 $\mathrm{G}>\mathrm{C}$ ) is common [minor allele frequency (MAF) $>0.05$ ] and regarded as a tagger, which was most frequently investigated for its association with cancer risk.

To date, molecular epidemiological studies have

${ }^{1}$ Department of Radiation Oncology, General Hospital of Beijing Military Command, Beijing, ${ }^{2}$ Department of Cardiothoracic Surgery, Shaoxing People's Hospital, Shaoxing Hospital of Zhejiang University, Shaoxing, Zhejiang Province, ${ }^{3}$ Cancer Center, Shanghai East Hospital, Tongji University School of Medicine, Shanghai, China \&Equal contributors *For correspondence: yajiewao459@163. com;wangyadi@hotmail.com 
Hua-Yong Jiang et al

investigated the relationship between the XPG Asp1104His polymorphism and predisposition to HNC. However, results of these studies are controversial; Therefore, we performed this meta-analysis in order to precisely assess the possible association of the XPG Asp1104His with the susceptibility to develop HNC.

Materials and Methods

\section{Search strategy}

A systematic and electronic search of the PubMed, EMBASE and Web of Science was performed to identify studies using combinations of the following search terms: "head and neck cancer", "oral cancer", "oropharyngeal cancer", "hypopharynx cancer" "laryngeal cancer", "pharyngeal cancer", "cancer", "tumor", "carcinoma", "nucleotide excision repair", "XPG", "ERCC5", "polymorphism", and "variation". All of the studies were

Table 1. Characteristics of Case-Control Studies Included in the Meta-Analysis

\begin{tabular}{|c|c|c|c|c|c|c|c|c|c|c|c|}
\hline \multicolumn{12}{|c|}{ No. of } \\
\hline Study & Year & Country & Gene test & Source & Site & $\begin{array}{c}\text { Case/ } \\
\text { Control }\end{array}$ & \multicolumn{3}{|c|}{ Case } & & \\
\hline $\begin{array}{c}\text { XPG } \\
\text { His1104Asp }\end{array}$ & & & & & & & GG & GC & $\mathrm{CC}$ & & \\
\hline $\mathrm{Lu} \mathrm{B}$ & 2014 & Asian & $\begin{array}{c}\text { MassARRAY } \\
\text { Analyzer }\end{array}$ & HB & Laryngeal & $176 / 176$ & 53 & 69 & 54 & & \\
\hline Li X & 2014 & Asian & $\begin{array}{c}\text { Sequenom } \\
\text { MassARRAY }\end{array}$ & HB & Laryngeal & $211 / 210$ & 64 & 79 & 68 & & \\
\hline Wyss AB & 2013 & Caucasian & $\begin{array}{c}\text { Illumina } \\
\text { GoldenGate } \\
\text { assay }\end{array}$ & PB & $\begin{array}{l}\text { head and } \\
\text { neck }\end{array}$ & $915 / 1066$ & 365 & & 550 & & \\
\hline $\mathrm{Ma} \mathrm{H}$ & 2012 & Caucasian & $\begin{array}{c}\text { ABI7900 } \\
\text { sequence } \\
\text { detection system }\end{array}$ & HB & $\begin{array}{l}\text { head and } \\
\text { neck }\end{array}$ & $1059 / 1056$ & 648 & 359 & 52 & & \\
\hline Yuan H & 2012 & Asian & $\begin{array}{c}\text { ABI7900 } \\
\text { sequence } \\
\text { detection system }\end{array}$ & HB & $\begin{array}{c}\text { head and } \\
\text { neck }\end{array}$ & $394 / 884$ & 108 & 191 & 95 & & \\
\hline Abbasi R & 2009 & Caucasian & PCR-RFLP & PB & Laryngeal & $248 / 647$ & 137 & 103 & 8 & & \\
\hline Wen SX & 2006 & Asian & PCR-RFLP & HB & $\begin{array}{l}\text { head and } \\
\text { neck }\end{array}$ & $175 / 525$ & 55 & 81 & 39 & & \\
\hline Cui Y & 2006 & Caucasian & PCR-RFLP & PB & $\begin{array}{l}\text { head and } \\
\text { neck }\end{array}$ & $443 / 911$ & 214 & 194 & 35 & & \\
\hline Study & Year & Country & Gene test & Source & Site & $\begin{array}{c}\text { Case/ } \\
\text { Control }\end{array}$ & \multicolumn{3}{|c|}{ Control } & HWE & NOS \\
\hline $\begin{array}{c}\text { XPG } \\
\text { His1104Asp }\end{array}$ & & & & & & & GG & GC & $\mathrm{CC}$ & & \\
\hline Lu B & 2014 & Asian & $\begin{array}{c}\text { MassARRAY } \\
\text { Analyzer }\end{array}$ & $\mathrm{HB}$ & Laryngeal & $176 / 176$ & 78 & 62 & 36 & 0 & 8 \\
\hline Li X & 2014 & Asian & $\begin{array}{c}\text { Sequenom } \\
\text { MassARRAY }\end{array}$ & HB & Laryngeal & $211 / 210$ & 88 & 73 & 49 & 0 & 8 \\
\hline Wyss AB & 2013 & Caucasian & $\begin{array}{l}\text { Illumina } \\
\text { GoldenGate } \\
\text { assay }\end{array}$ & PB & $\begin{array}{c}\text { head and } \\
\text { neck }\end{array}$ & $915 / 1066$ & 415 & & 651 & - & 7 \\
\hline $\mathrm{Ma} \mathrm{H}$ & 2012 & Caucasian & $\begin{array}{c}\text { ABI7900 } \\
\text { sequence } \\
\text { detection system }\end{array}$ & HB & $\begin{array}{l}\text { head and } \\
\text { neck }\end{array}$ & $1059 / 1056$ & 654 & 350 & 52 & 0.56 & 8 \\
\hline Yuan H & 2012 & Asian & $\begin{array}{c}\text { ABI7900 } \\
\text { sequence } \\
\text { detection system }\end{array}$ & HB & $\begin{array}{l}\text { head and } \\
\text { neck }\end{array}$ & $394 / 884$ & 234 & 433 & 217 & 0.55 & 9 \\
\hline Abbasi R & 2009 & Caucasian & PCR-RFLP & PB & Laryngeal & $248 / 647$ & 380 & 230 & 37 & 0.78 & 8 \\
\hline Wen SX & 2006 & Asian & PCR-RFLP & HB & $\begin{array}{l}\text { head and } \\
\text { neck }\end{array}$ & $175 / 525$ & 129 & 296 & 100 & 0 & 9 \\
\hline Cui Y & 2006 & Caucasian & PCR-RFLP & PB & $\begin{array}{l}\text { head and } \\
\text { neck }\end{array}$ & $443 / 911$ & 474 & 357 & 80 & 0.28 & 8 \\
\hline
\end{tabular}

*HB hospital based, PB population based; HWE: Hardy-Weinberg equilibrium; PCR: Polymerase chain reaction; RFLP: Restriction fragment length polymorphism. NOS: Newcastle-Ottawa Scale 
published from their earliest entry points to Dec 18, 2014. The search was limited to human studies and performed without any restrictions on language.

Inclusion criteria were defined as follows: (1) Studies that evaluated the association between the $X P G$ Asp1104His polymorphism and HNC risk; (2) Casecontrol studies; (3) Studies with full-text article; (4) Sufficient data for estimating an odds ratio (OR) with 95\% confidence interval (CI). (5) When duplicated studies were published by the same author obtained from the same patient sample, only the most complete publication study was included in this meta-analysis. Unpublished reports and abstracts were not considered.

\section{Data extraction and quality assessment}

Information was extracted carefully from all eligible publications independently by two investigators according to the inclusion criteria listed above. For conflicting evaluation, an agreement was reached following discussion. Data extracted from the selected articles included the first author's name, year of publication, country of origin, ethnicity, tumor site, genotyping methods, source of control, number of cases and controls. Ethnicities were categorized as Asian and Caucasian. Source of control were categorized as population based and hospital based. Tumor sites were categorized as laryngeal and mixed HNC. We did not define any minimum number of patients to include in our metaanalysis. The methodological quality of included studies was assessed using the Newcastle-Ottawa Scale (NOS) (Stang, 2010) for quality of case control and cohort studies in this meta-analysis, a study awarded 7 or more stars as a high-quality study.

\section{Statistical analysis}

Pooled Odds ratios (ORs) with $95 \%$ confidence intervals (CIs) were used to evaluate the association between the $X P G$ Asp1104His polymorphism and susceptibility to HNC. Although fixed-effects model and random-effects model yielded similar conclusions, many investigators considered that the random-effects model was a more natural choice than fixed-effects model in medical decision-making contexts (DerSimonian and Laird, 1986; Ades et al., 2005). So we chose to use the random-effects model with Mantel-Haenszel statistics (Mantel and Haenszel, 1959; Laird and Ware, 1982), which assumed that the true underlying effect varied among included studies. First, the pooled ORs were performed for co-dominant model (CC vs GG and GC vs GG), the dominant model (CC+GC vs GG), and the recessive model (CC vs $\mathrm{GC}+\mathrm{GG})$, respectively. For subgroup analysis, ethnicity, source of control, and tumor sites were analyzed statistically. Heterogeneity among the studies was assessed using the chi-square-based $\mathrm{Q}$ statistic $(\mathrm{P}<0.05$ for the $\mathrm{Q}$ test indicates significant heterogeneity) (Cochran, 1954). We also quantified the effect of heterogeneity using the $\mathrm{I} 2$ statistic (Higgins and Thompson, 2002). Venice criteria (Ioannidis et al., 2008) for $\mathrm{I}^{2}$ test: ' $\mathrm{I}^{2}<25 \%$ represents no heterogeneity, $\mathrm{I}^{2}=25 \sim 50 \%$ represents moderate heterogeneity, $\mathrm{I}^{2}=50 \sim 75 \%$ represents significant heterogeneity, $\mathrm{I}^{2}>75 \%$ represents extreme heterogeneity. Finally, potential publication bias was evaluated through Begg's test and Egger's test by visual analysis of the funnel plot (Begg and Mazumdar, 1994; Egger et al., 1997), $\mathrm{P}<0.05$ was considered statistically significant publication bias. Hardy-Weinberg equilibrium in controls was calculated in our meta-analysis. The chisquared goodness-of-fit test was used to test deviation from Hardy-Weinberg equilibrium (HWE; $\mathrm{P}<0.05$ was considered significant). Meta-analysis was performed using the STATA statistical software (version 10.0). All the $\mathrm{P}$ values were two-sided.

\section{Results}

\section{Study characteristics}

The flow chart of study selection in summarized in Figure 1 . The search strategy retrieved 193 potentially relevant studies. According to the inclusion criteria, as summarized in Table 1, a total of 8 eligible studies (Cui et al., 2006; Wen et al., 2006; Abbasi et al., 2009; Ma et al., 2012; Yuan et al., 2012; Wyss et al., 2013; Li et al., 2014; Lu et al., 2014) including 3, 621 cases and 5, 475 controls were included in the meta-analysis. All of the cases were histologically confirmed. The controls were primarily healthy population. In those included studies, four studies (Wen et al., 2006; Yuan et al., 2012; Li et al., 2014; Lu et al., 2014) were performed in Asians and four

Table 2. Main Results of Pooled Odds Ratios (OR) with Confidence Interval (CI) in the Meta-Analysis in Overall Population

\begin{tabular}{|c|c|c|c|c|c|c|c|c|c|c|c|}
\hline \multirow{2}{*}{$\begin{array}{l}\text { Polymor } \\
\text { phism }\end{array}$} & \multirow{2}{*}{ Genetic model } & \multirow{2}{*}{$\begin{array}{l}\text { Genetic } \\
\text { type }\end{array}$} & \multicolumn{3}{|c|}{ Heterogeneity test } & \multirow{2}{*}{ OR $(95 \%$ CI $)$} & \multirow{2}{*}{ P1 } & \multicolumn{2}{|c|}{ Begg's test } & \multicolumn{2}{|c|}{$\begin{array}{c}\text { Egger's } \\
\text { test }\end{array}$} \\
\hline & & & $\mathbf{Q}$ & $I^{2}(\%)$ & PH & & & $\mathbf{Z}$ & $\mathbf{P 2}$ & $\mathbf{t}$ & P3 \\
\hline \multirow{4}{*}{$\begin{array}{c}\text { XPG } \\
\text { His1104Asp }\end{array}$} & \multirow{2}{*}{$\begin{array}{l}\text { Codominant } \\
\text { model }\end{array}$} & $\begin{array}{c}\mathrm{CC} \text { vs } \\
\text { GG }\end{array}$ & 15.2 & $60.50 \%$ & 0.02 & $1.11(0.94 \sim 1.31)$ & 0.24 & 0.3 & 0.76 & 0.3 & 0.78 \\
\hline & & $\begin{array}{c}\text { GC vs } \\
\text { GG }\end{array}$ & 13.71 & $56.30 \%$ & 0.03 & $1.09(0.98 \sim 1.21)$ & 0.12 & 0.9 & 0.37 & 0.46 & 0.67 \\
\hline & $\begin{array}{c}\text { Dominant } \\
\text { model }\end{array}$ & $\begin{array}{l}\mathrm{CC}+\mathrm{GC} \\
\text { vs GG }\end{array}$ & 16.47 & $63.60 \%$ & 0.01 & $1.10(0.99 \sim 1.22)$ & 0.07 & 0.9 & 0.37 & 0.91 & 0.41 \\
\hline & $\begin{array}{c}\text { Recessive } \\
\text { model }\end{array}$ & $\begin{array}{c}\mathrm{CC} \text { vs } \\
\mathrm{GC}+\mathrm{GG}\end{array}$ & 12.2 & $42.60 \%$ & 0.09 & $1.03(0.92 \sim 1.16)$ & 0.57 & 1.11 & 0.27 & 0.59 & 0.58 \\
\hline
\end{tabular}

*PH value for heterogeneity; Po value for OR; Pb value for Begg's test; Pe value for Egger's test; OR: Odds ratio; CI: Confidence interval 
Hua-Yong Jiang et al

Table 3. Main Results of Pooled Odds Ratios (OR) with Confidence Interval (CI) in the Meta-Analysis by Ethnicity, Source of Controls and Tumor Site

\begin{tabular}{|c|c|c|c|c|c|c|c|c|c|c|c|}
\hline $\begin{array}{l}\text { Polymor } \\
\text { phism }\end{array}$ & $\begin{array}{c}\text { Subgroup } \\
(\mathrm{N})\end{array}$ & $\begin{array}{l}\text { Genetic } \\
\text { type }\end{array}$ & \multicolumn{3}{|c|}{ Heterogeneity test } & \multirow{2}{*}{ OR $(95 \% \mathrm{CI})$} & \multirow{2}{*}{ P1 } & \multicolumn{2}{|c|}{ Begg's test } & \multicolumn{2}{|c|}{ Egger's test } \\
\hline \multicolumn{3}{|c|}{ Asp148Glu } & Q & $\mathrm{I}^{2}(\%)$ & $\mathrm{PH}$ & & & $\mathrm{Z}$ & $\mathrm{P} 2$ & $\mathrm{t}$ & P3 \\
\hline \multirow{8}{*}{ Race } & \multirow{4}{*}{ Asian (4) } & $\mathrm{CC}$ vs GG & 11.27 & $73.40 \%$ & 0.01 & $1.24(1.00 \sim 1.54)$ & 0.05 & 1.7 & 0.09 & 6.05 & 0.28 \\
\hline & & GC vs GG & 11.62 & $74.20 \%$ & 0.01 & $1.03(0.85 \sim 1.24)$ & 0.77 & 1.02 & 0.31 & 3.85 & 0.51 \\
\hline & & $\begin{array}{c}\mathrm{CC}+\mathrm{GC} \text { vs } \\
\mathrm{GG}\end{array}$ & 15.65 & $80.80 \%$ & 0 & $1.11(0.93 \sim 1.32)$ & 0.24 & 1.02 & 0.31 & 5.69 & 0.43 \\
\hline & & $\begin{array}{c}\mathrm{CC} \text { vs } \\
\mathrm{GC}+\mathrm{GG}\end{array}$ & 5.67 & $47.10 \%$ & 0.13 & $1.22(1.01 \sim 1.46)$ & 0.04 & 1.7 & 0.09 & 5.03 & 0.05 \\
\hline & \multirow{4}{*}{$\begin{array}{c}\text { Caucasian } \\
\text { (4) }\end{array}$} & $\mathrm{CC}$ vs GG & 1.39 & $0.00 \%$ & 0.5 & $0.93(0.71 \sim 1.22)$ & 0.58 & 1.04 & 0.3 & -2.62 & 0 \\
\hline & & GC vs GG & 1.51 & $0.00 \%$ & 0.47 & $1.12(0.98 \sim 1.28)$ & 0.09 & 1.04 & 0.3 & 3.27 & 0.24 \\
\hline & & $\begin{array}{c}\mathrm{CC}+\mathrm{GC} \text { vs } \\
\mathrm{GG}\end{array}$ & 0.81 & $0.00 \%$ & 0.68 & $1.10(0.99 \sim 1.22)$ & 0.17 & 0 & 1 & 2.11 & 0.37 \\
\hline & & $\begin{array}{c}\mathrm{CC} \text { vs } \\
\mathrm{GC}+\mathrm{GG}\end{array}$ & 2.03 & $0.00 \%$ & 0.57 & $0.93(0.80 \sim 1.08)$ & 0.37 & 1.7 & 0.09 & -1.12 & 0.26 \\
\hline \multirow{8}{*}{ Source } & \multirow{4}{*}{ HB (5) } & $\mathrm{CC}$ vs GG & 12.05 & $66.80 \%$ & 0.02 & $1.19(0.98 \sim 1.43)$ & 0.08 & 1.71 & 0.09 & 6.25 & 0.16 \\
\hline & & GC vs GG & 11.63 & $65.60 \%$ & 0.02 & $1.03(0.90 \sim 1.17)$ & 0.64 & 0.73 & 0.46 & 0.96 & 0.7 \\
\hline & & $\begin{array}{c}\mathrm{CC}+\mathrm{GC} \text { vs } \\
\mathrm{GG}\end{array}$ & 15.94 & $74.90 \%$ & 0 & $1.07(0.95 \sim 1.21)$ & 0.28 & 0.73 & 0.46 & 2.04 & 0.5 \\
\hline & & $\begin{array}{c}\mathrm{CC} \text { vs } \\
\mathrm{GC}+\mathrm{GG}\end{array}$ & 6.45 & $38.00 \%$ & 0.17 & $1.17(0.99 \sim 1.39)$ & 0.07 & 2.2 & 0.03 & 4.65 & 0.08 \\
\hline & \multirow{4}{*}{ PB (3) } & CC vs GG & 1.1 & $9.10 \%$ & 0.29 & $0.86(0.59 \sim 1.25)$ & 0.43 & 0 & 1 & -2.61 & - \\
\hline & & GC vs GG & 0.03 & $0.00 \%$ & 0.87 & $1.22(1.01 \sim 1.47)$ & 0.04 & 0 & 1 & 0.94 & - \\
\hline & & $\begin{array}{c}\mathrm{CC}+\mathrm{GC} \text { vs } \\
\text { GG }\end{array}$ & 0 & $0.00 \%$ & 0.97 & $1.16(0.97 \sim 1.39)$ & 0.11 & 0 & 1 & -0.19 & - \\
\hline & & $\begin{array}{c}\mathrm{CC} \text { vs } \\
\mathrm{GC}+\mathrm{GG}\end{array}$ & 1.92 & $42.60 \%$ & 0.09 & $0.92(0.79 \sim 1.09)$ & 0.33 & 1.04 & 0.3 & -1.46 & 0.25 \\
\hline \multirow{8}{*}{ Site } & \multirow{4}{*}{ Laryngeal (3) } & $\mathrm{CC}$ vs GG & 7.78 & $74.30 \%$ & 0.02 & $1.59(1.16 \sim 2.19)$ & 0 & 0 & 1 & -7.91 & 0.25 \\
\hline & & GC vs GG & 1.04 & $0.00 \%$ & 0.6 & $1.38(1.10 \sim 1.72)$ & 0.01 & 1.04 & 0.3 & 2.71 & 0.09 \\
\hline & & $\begin{array}{c}\mathrm{CC}+\mathrm{GC} \text { vs } \\
\mathrm{GG}\end{array}$ & 3.86 & $48.20 \%$ & 0.15 & $1.42(1.15 \sim 1.74)$ & 0 & 1.04 & 0.3 & 6.52 & 0.02 \\
\hline & & $\begin{array}{c}\mathrm{CC} \text { vs } \\
\mathrm{GC}+\mathrm{GG}\end{array}$ & 6.51 & $69.30 \%$ & 0.04 & $1.36(1.02 \sim 1.81)$ & 0.04 & 0 & 1 & -6.12 & 0.21 \\
\hline & \multirow{4}{*}{ Mixed (5) } & CC vs GG & 0.1 & $0.00 \%$ & 0.99 & $0.96(0.79 \sim 1.18)$ & 0.7 & 0.34 & 0.73 & -0.22 & 0.81 \\
\hline & & GC vs GG & 7.23 & $58.50 \%$ & 0.07 & $1.02(0.90 \sim 1.15)$ & 0.8 & 1.02 & 0.31 & -3.7 & 0.27 \\
\hline & & $\begin{array}{c}\mathrm{CC}+\mathrm{GC} \text { vs } \\
\mathrm{GG}\end{array}$ & 5.03 & $40.40 \%$ & 0.17 & $1.01(0.90 \sim 1.34)$ & 0.84 & 1.02 & 0.31 & -3.22 & 0.26 \\
\hline & & $\begin{array}{c}\mathrm{CC} \text { vs } \\
\mathrm{GC}+\mathrm{GG}\end{array}$ & 1.3 & $0.00 \%$ & 0.86 & $0.98(0.86 \sim 1.12)$ & 0.78 & 0.73 & 0.46 & 0.57 & 0.52 \\
\hline
\end{tabular}

*N for numbers of studies; PH value for heterogeneity; Po value for OR; Pb value for Begg's test; Pe value for Egger's test; OR: Odds ratio; CI: Confidence interval

(Cui et al., 2006; Abbasi et al., 2009; Ma et al., 2012; Wyss et al., 2013) were conducted in Caucasians. Five studies (Wen et al., 2006; Ma et al., 2012; Yuan et al., 2012; Li et al., 2014; Lu et al., 2014) were hospital-based, three studies (Cui et al., 2006; Abbasi et al., 2009; Wyss et al., 2013) were population-based. Three studies (Abbasi et al., 2009; Li et al., 2014; Lu et al., 2014) was performed on laryngeal cancer, five studies (Cui et al., 2006; Wen et al., 2006; Ma et al., 2012; Yuan et al., 2012; Wyss et al., 2013) on mixed cancers. Consequently, we performed subgroup analysis by stratification of ethnicity, source of controls and cancer type. Details of subjects in these studies were outlined in Table 1. Studies with control not in HardyWeinberg equilibrium (HWE) were also considered for meta-analysis, but they were excluded in the sensitivity analysis (Minelli et al., 2008).

\section{Main meta-analysis results}

The main results of our meta-analysis under four distinct genetic models were listed in Table 2and Table 3. Overall, the $X P G$ Asp1104His polymorphism had no association with increased $\mathrm{HNC}$ risk under all four genetic models (CC $v s \mathrm{GG}$ : $\mathrm{OR}=1.11,95 \% \mathrm{CI}=0.94 \sim 1.31, P=0.02$, Figuer 2A; GC vs GG: $\mathrm{OR}=1.09,95 \% \mathrm{CI}=0.98 \sim 1.21$, 


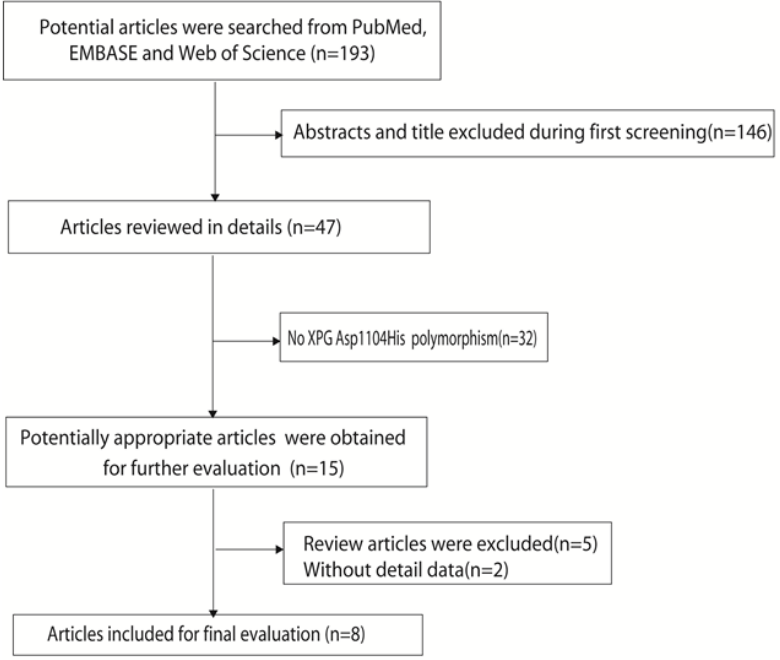

Figure 1. Study Selection Process for the Meta-Analysis

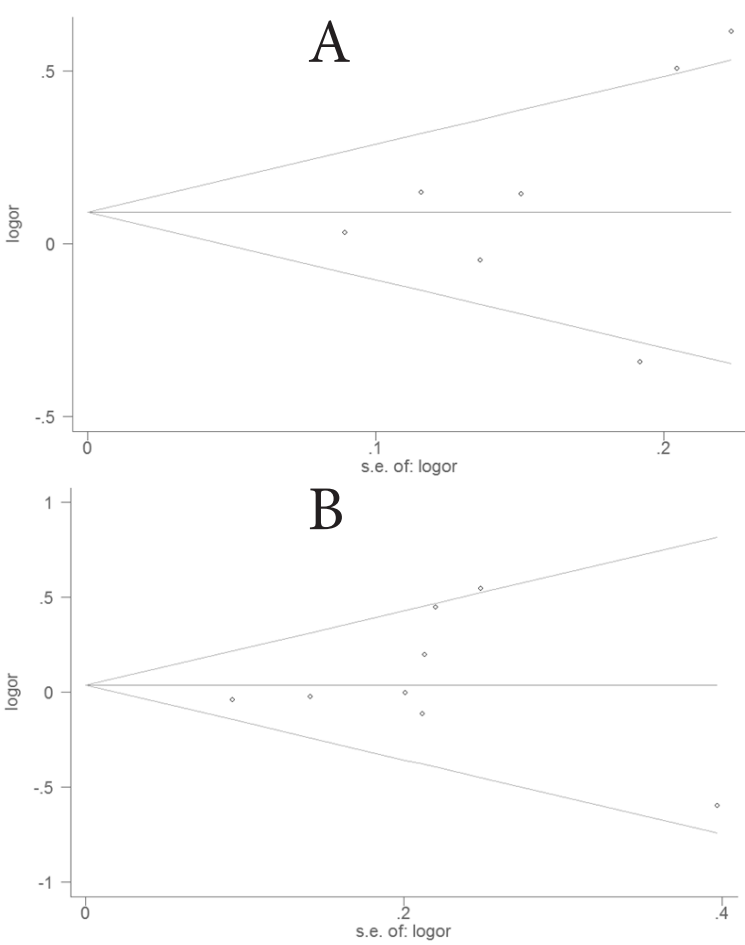

Figure 3. Publication Bias in Studies of the Relation between the XPG Asp1104His polymorphism and HNC Susceptibility Under the Dominant Model and the Recessive Model. A funnel plot with pseudo-95\% confidence limits (dashed lines) was used

$P=0.03$, Figuer $2 \mathrm{~B}$; dominant model: $\mathrm{OR}=1.10,95 \%$ $\mathrm{CI}=0.99 \sim 1.22 ; P=0.01$, Figuer $2 \mathrm{C}$; recessive model: $\mathrm{OR}=1.03,95 \% \mathrm{CI}=0.92 \sim 1.16, P=0.09$, Figuer $2 \mathrm{D})$.

In the subgroup analysis by ethnicity, the $X P G$ Asp1104His polymorphism had statistically significant association with elevated $\mathrm{HNC}$ risk under CC vs GG $(\mathrm{OR}=1.24,95 \% \mathrm{CI}=1.00 \sim 1.54)$ and the recessive model $(\mathrm{OR}=1.22,95 \% \mathrm{CI}=1.01 \sim 1.46)$ in Asian population.

In the subgroup analysis by source of control, the $X P G$ Asp1104His polymorphism had statistically significant association with elevated $\mathrm{HNC}$ risk under CC vs GG $(\mathrm{OR}=1.22,95 \% \mathrm{CI}=1.01 \sim 1.47)$ in the population based

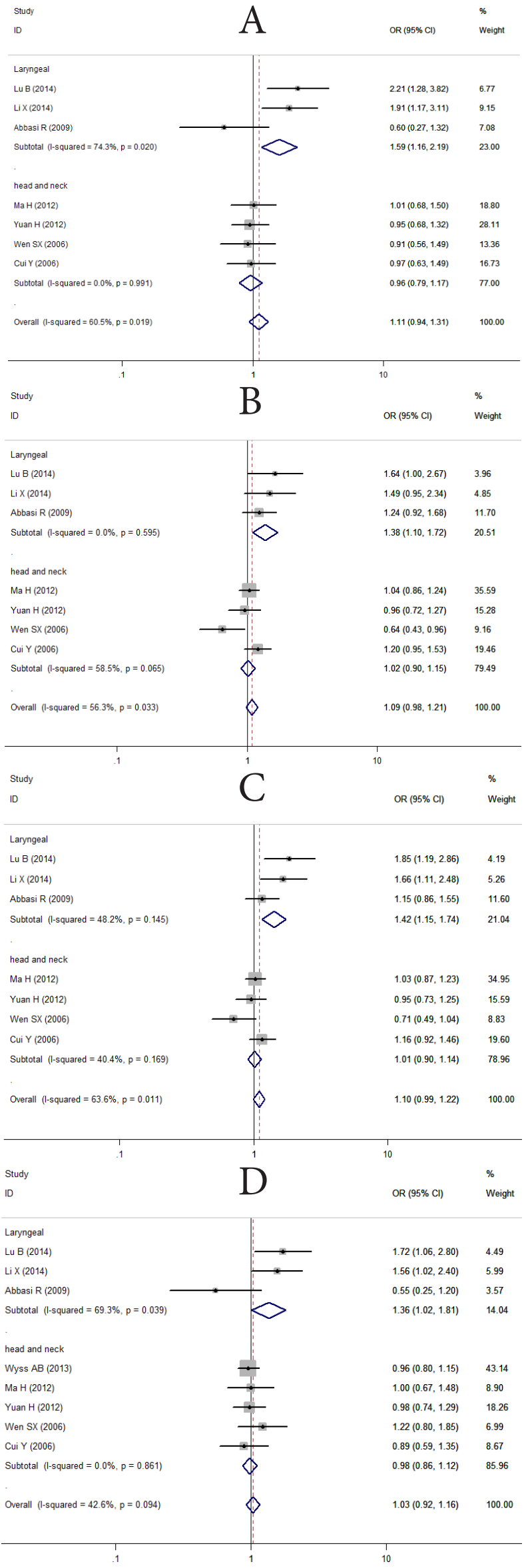

Figure 2. Odds ratios (ORs) for associations between the XPG Asp1104His polymorphism and HNC susceptibility. 
subgroup.

In the subgroup analysis by cancer type, the $X P G$ Asp1104His polymorphism had statistically significant association with elevated laryngeal cancer under all genetic models (CC vs GG: OR=1.59, 95\% CI=1.16 2.19, Figuer 2A; GC vs GG: OR=1.38, 95\% CI=1.10 1.72, Figuer 2B; dominant model: $\mathrm{OR}=1.42,95 \% \mathrm{CI}=1.15 \sim 1.74$, Figuer $2 \mathrm{C}$; recessive model: $\mathrm{OR}=1.36,95 \% \mathrm{CI}=1.02 \sim 1.81$, Figuer 2D).

\section{Heterogeneity and sensitivity analysis}

As showed in Table 2 and Table 3, there was statistically heterogeneity among these studies in overall comparisons $(P<0.05)$, in the stratified analysis by ethnicity, source of control and tumor site, heterogeneity was also found in Asian, hospital based population and laryngeal cancer, but not found in some models in Caucasian, population based population.

\section{Publication bias}

Begg's funnel plot and Egger's test were performed to assess the potential publication bias in the available literature. The shape of funnel plots did not reveal any evidence of funnel plot asymmetry under the dominant model (Figuer 3A) and the recessive model (Figuer 3B). Egger's test also showed that there was no statistical significance for the evaluation of publication bias (CC vs GG: $P=0.78$, GC vs GG: $P=0.67$, dominant model: $P=0.41$, recessive model: $P=0.58$ ).

\section{Discussion}

DNA repair mechanisms play a critical role in the protection of cells from DNA damage and in the maintenance of genomic integrity. The nucleotide excision repair (NER) pathway is the primary mechanism for removal of bulky adducts from DNA, and thus is an important part of the cellular defense against a large variety of structural unrelated DNA lesions; The NER pathway includes several steps: The first step for NER pathway involves damage recognition by a complex of bound proteins, including $X P C$ ); The next step involves unwinding of the DNA by a complex including XPD and removal of the damaged single-stranded nucleotide fragment by molecules including XPG, ERCC1, and XPF (Tse et al., 2008; Machado et al., 2014; McCullough et al., 2014).

$X P G$ is a NER pathway gene with an important role in the repair of DNA damage induced by exposure to environmental and biological mutagens or normal cellular metabolism. The XPG deficiency leads to DNA repair incapability, genomic instability, gene transcription. Abnormality, and facilitates cancer development (Cheng et al., 2002), Single nucleotide polymorphism (SNP) is the most common genetic variant in the genome; subtle functional alterations in SNPs may result in significant biological outcomes (Bernig and Chanock, 2006). Several genetic association studies have connected $X P G$ Asp1104His polymorphism with HNC risk in the recent decade. However, the results contradict each other. To shed light on the association between the XPG Asp1104His polymorphism and HNC risk, we performed a metaanalysis involving eight case-control studies (9, 096 subjects). The summary OR of all case-control studies suggested no overall association for all genetic models adopted. Subgroup analyses were performed according to ethnicity and source of control, the results revealed the XPG Asp1104His polymorphism had statistically significant association with elevated HNC risk in Asian population and in the population based subgroup. The relationship between the XPG Asp1104His polymorphism and HNC susceptibility might be affected by the tumor sites. Accordingly, we also performed stratified analysis in the laryngeal cancer group, the result of this subgroup analysis showed a significant association between the $X P G$ Asp1104His polymorphism and the risk of laryngeal cancer under all genetic models.

Although we have put considerable efforts and resources into testing possible association between the $X P G$ Asp1104His polymorphism and HNC risk, there are still some limitations inherited from the published studies. First, a common limitation of meta-analysis was heterogeneity, heterogeneity was often caused by variation in the environmental and genetic background of study participants, which was unavoidable when combing many studies, and we found evidence of study heterogeneity in our study, presumably because of the ethnicity, source of control and tumor site. Second, the controls were not uniformly defined. Some studies used a healthy population as the reference group, whereas others selected hospital patients without organic breast cancer as the reference group. Therefore, non-differential misclassification bias is possible because these studies may have included the control groups who have different risks of developing breast cancer. Third, the overall outcomes were based on unadjusted estimates, while a more precise evaluation should be adjusted by other co-variants including tobacco use, alcohol consumption, viral infection, and environment factors if individual data were available.

In conclusion, our meta-analysis suggested that the $X P G$ Asp1104His polymorphism was a risk factor for HNC susceptibility, especially in laryngeal cancer and in Asian population. However, further studies with large sample sizes are needed to investigate the association between the XPG Asp1104His polymorphisms and HNC susceptibility.

\section{References}

Abbasi R, Ramroth H, Becher H, et al (2009). Laryngeal cancer risk associated with smoking and alcohol consumption is modified by genetic polymorphisms in ERCC5, ERCC6 and RAD23B but not by polymorphisms in five other nucleotide excision repair genes. Int J Cancer, 125, 1431-19.

Ades AE, Lu G, Higgins JP(2005). The interpretation of randomeffects meta-analysis in decision models. Med Decis Making, 25, 646-54.

Arora S, Aggarwal P, Pathak A (2012). Molecular genetics of head and neck cancer. Mol Med Rep, 6, 19-22.

Begg CB, Mazumdar M (1994). Operating characteristics of a rank correlation test for publication bias. Biometrics, 50, 1088-101. 
Bernig T, Chanock SJ (2006). Challenges of SNP genotyping and genetic variation: its future role in diagnosis and treatment of cancer. Expert Rev Mol Diagn, 6, 319-31.

Cheng L, Sturgis EM, Eicher SA, Spitz MR, Wei Q (2002). Expression of nucleotide excision repair genes and the risk for squamous cell carcinoma of the head and neck. Cancer, 94, 393-7.

Clarkson SG (2003). The XPG story. Biochimie, 85, 1113-21.

Cochran WG (1954). The combination of estimates from different experiments. Biometrics, 10, 101-2.

Cui Y, Morgenstern H, Greenland S, et al (2006). Polymorphism of Xeroderma Pigmentosum group $\mathrm{G}$ and the risk of lung cancer and squamous cell carcinomas of the oropharynx, larynx and esophagus. Int J Cancer, 118, 714-20.

DerSimonian R, Laird N (1986). Meta-analysis in clinical trials. Control Clin Trials, 7, 177-88.

Egger M, Davey SG, Schneider M, Minder C (1997) Bias in metaanalysis detected by a simple, graphical test. $B M J$, 315, 629-34.

Emmert S, Schneider TD, Khan SG, Kraemer KH (2001). The human $X P G$ gene: gene architecture, alternative splicing and single nucleotide polymorphisms. Nucleic Acids Res, 29, 1443-52.

Higgins JP, Thompson SE (2002). Quantifying heterogeneity in a metaanalysis. Stat Med, 21, 1539-58.

Hopkins J, Cescon DW, Tse D, et al (2008). Genetic polymorphisms and head and neck cancer outcomes: a review. Cancer Epidemiol Biomarkers Prev, 17, 490-9.

Ioannidis JP, Boffetta P, Little J, et al (2008). Assessment of cumulative evidence on genetic associations: interim guidelines. Int J Epidemiol, 37, 120-32.

Laird NM, Ware JH (1982). Random-effects models for longitudinal data. Biometrics, 38, 963-74.

Li X, Xu J, Yang X, et al (2014). Association of single nucleotide polymorphisms of nucleotide excision repair genes with laryngeal cancer risk and interaction with cigarette smoking and alcohol drinking. Tumour Biol, 35, 4659-65.

Liu Y, Dong XL, Tian C, Liu HG (2012). Human telomerase RNA component (hTERC) gene amplification detected by FISH in precancerous lesions and carcinoma of the larynx. Diagn Pathol, 7, 34.

Lu B, Li J, Gao Q, et al (2014). Laryngeal cancer risk and common single nucleotide polymorphisms in nucleotide excision repair pathway genes ERCC1, ERCC2, ERCC3, ERCC4, ERCC5 and XPA. Gene, 542, 64-8.

$\mathrm{Ma} \mathrm{H}, \mathrm{Yu} \mathrm{H}$, Liu Z, et al (2012). Polymorphisms of XPG/ERCC5 and risk of squamous cell carcinoma of the head and neck. Pharmacogenet Genomics, 22, 50-7.

Machado CR, Vieira-da-Rocha JP, Mendes IC, et al (2014). Nucleotide excision repair in Trypanosoma brucei: specialization of transcription-coupled repair due to multigenic transcription. Mol Microbiol, 92, 756-76.

Mantel N, Haenszel W (1959). Statistical aspects of the analysis of data from retrospective studies of disease. J Natl Cancer Inst, 22, 719-48.

McCullough LE, Santella RM, Cleveland RJ, et al (2014). Polymorphisms in DNA repair genes, recreational physical activity and breast cancer risk. Int J Cancer, 134, 654-63.

Melis JP, van Steeg H, Luijten M (2013) Oxidative DNA damage and nucleotide excision repair. Antioxid Redox Signal, 18, 2409-19.

Minelli C, Thompson JR, Abrams KR, Thakkinstian A, Attia J (2008). How should we use information about HWE in the meta-analyses of genetic association studies? Int $J$ Epidemiol, 37, 136-46.

Mokhtari S (2012). Mechanisms of cyst formation in metastatic lymph nodes of head and neck squamous cell carcinoma.
Diagn Pathol, 7, 6.

Shamaa AA, Zyada MM, Wagner M, et al (2008). The significance of Epstein Barr virus (EBV) \& DNA topoisomerase II alpha (DNA-Topo II alpha) immunoreactivity in normal oral mucosa, oral epithelial dysplasia (OED) and oral squamous cell carcinoma (OSCC). Diagn Pathol, 3, 45.

Siegel R, Ma J, Zou Z, Jemal A (2014). Cancer statistics, 2014. CA Cancer J Clin, 64, 9-29.

Siegel R, Naishadham D, Jemal A (2012). Cancer Statistics. $C A$ Cancer J Clin, 62, 10-29.

Smith EM, Rubenstein LM, Haugen TH, Pawlita M, Turek LP (2012). Complex etiology underlies risk and survival in head and neck cancer human papillomavirus, tobacco, and alcohol: a case for multifactor disease. J Oncol, 2012, 571862 .

Stang A (2010). Critical evaluation of the Newcastle-Ottawa scale for the assessment of the quality of nonrandomized studies in meta-analyses. Eur J Epidemiol, 25, 603-5.

Tse D, Zhai R, Zhou W, et al (2008). Polymorphisms of the NER pathway genes, ERCC1 and XPD are associated with esophageal adenocarcinoma risk. Cancer Causes Control, 19, 1077-83.

Wen SX, Tang PZ, Zhang XM, et al (2006). Association between genetic polymorphism in xeroderma pigmentosum $\mathrm{G}$ gene and risks of laryngeal and hypopharyngeal carcinomas. Zhongguo Yi Xиe Ke Xue Yuan Xие Bao, 28, 703-6.

Wyss AB, Herring AH, Avery CL, et al (2013). Single-nucleotide polymorphisms in nucleotide excision repair genes, cigarette smoking, and the risk of head and neck cancer. Cancer Epidemiol Biomarkers Prev, 22, 1428-45.

Yuan H, Li H, Ma H, et al (2012). Genetic polymorphisms in key DNA repair genes and risk of head and neck cancer in a Chinese population. See comment in PubMed Commons below. Exp Ther Med, 3, 719-24. 